Wojciech Bagiński

Muzeum Pałacu Króla Jana III w Wilanowie

e-mail: wbaginski@muzeum-wilanow.pl

\title{
Opieka nad zabytkami z perspektywy posthumanistycznej Przypadek kolekcji wilanowskiej"
}

DOI: http://dx.doi.org/10.12775/RF.2017.012

\section{Wstęp}

W licznych organizacjach i przedsięwzięciach zaangażowanych w opiekę nad dziedzictwem kulturowym wciąż funkcjonują antropocentryczne schematy myślowe spychające na daleki margines wszystko, co nie jest aktywnością pochodzącą bezpośrednio od zespołów ludzkich czy poszczególnych osób. Obiekty i kolekcje zabytkowe są tam postrzegane jako całkowicie bierne przedmioty interwencji, uwaga zaś najczęściej koncentruje się na samej interwencji, jako akcie całkowicie intencjonalnym i kontrolowanym przez ludzi. Jest to widoczne w tematyce konferencji poświęconych opiece nad dziedzictwem kulturowym, podczas których głównymi wątkami prezentacji są techniczne opisy działań prowadzonych przez ludzi. Ranga poddawanego zabiegom dzieła sztuki podnosi tylko rangę wykonywanych operacji, których - jak na ogół słyszymy - inicjatorami, projektantami i wykonawcami są relacjonujący je

Artykuł jest fragmentem przygotowywanej przez autora rozprawy doktorskiej na Wydziale Konserwacji i Restauracji Dzieł Sztuki Akademii Sztuk Pięknych w Warszawie, zatytułowanej: Konserwacja murów XVIII wiecznego spichlerza w Wilanowie. Teoria Aktora-Sieci (ANT) jako narzędzie wspomagajace proces konserwatorski. Adres kontaktowy autora: wbaginski@muzeum-wilanow.pl. 
konserwatorzy, w niektórych przypadkach reprezentujący szersze gremia zawodowe.

Pytanie, na które próbuję w niniejszym tekście odpowiedzieć (lub przynajmniej zaproponować obszar, w którym odpowiedzi warto poszukiwać), to pytanie o kondycję zawodu konserwatora zabytków w świecie, który ze względu na coraz silniejsze powiązanie tego, co ludzkie, z tym, co techniczne, elektroniczne, cyfrowe oraz przyrodnicze, na naszych oczach podaje $\mathrm{w}$ wątpliwość samą istotę definiującego nowoczesność dualizmu podmiot-przedmiot (kultura-natura, ludzieczynniki pozaludzkie (non-humans), intencjonalność ludzka-sprawczość przedmiotów). Jeśli naprawdę „nigdy nie byliśmy nowocześni” - jak to sugeruje tytuł bodaj najważniejszej książki Brunona Latoura, jednego z współtwórców Teorii Aktora-Sieci (ANT) - to czy zmienia to nasz sposób myślenia o opiece nad zabytkami? ${ }^{1}$ Analizowanym w tekście przypadkiem empirycznym, na podstawie którego będziemy szukali odpowiedzi na postawione wyżej pytanie jest proces prewencji konserwatorskiej w Muzeum Pałacu Króla Jana III w Wilanowie.

Z pomocą teoretyczną i metodologiczną przyjdzie nam właśnie wywodząca się z gruntu badań STS (Science and Technology Studies) Teoria Aktora-Sieci, która analizując przyczyny aktualnego stanu społeczeństwa, nauki i techniki, po raz pierwszy tak wyraźnie i tak przekonująco wyartykułowała tezę o złudności sądu, jakobyśmy niepodzielnie, czy to jako jednostki, czy jako społeczeństwo, decydowali o tym, co bę-

1 Jak pisze francuski filozof, nowoczesność od początku do końca była stanem ułudy. Według wywodu zamieszczonego w tejże pracy, do brzemiennej w skutkach pomyłki doszło w trakcie debaty Robert Boyle -Thomas Hobbes, toczonej ok. $1660 \mathrm{r}$. wokół eksperymentów Boyle'a z pompą próżniową. Ukonstytuował się wtedy podział na "rzeczy same w sobie" (biegun Boyle'a) i "ludzi samych pomiędzy sobą" (biegun Hobbesa), a istota pomyłki polegała na tym, że obaj adwersarze przestali dostrzegać połączenia pomiędzy tymi biegunami. Niestety, te połączenia pozostały „przezroczyste” dla następców Boyle'a i Hobbesa na długie lata, a biegunowe, dualistyczne podejście stało się fundamentem i siłą napędową projektu nowoczesnego. Ostatecznie, wskutek dramatycznego, współczesnego zagęszczenia sieci powiązań między tym, co ludzkie i czynnikami pozaludzkimi, nie sposób dłużej powiązań tych nie dostrzegać. W książce Latoura czytamy: „Kiedy chodziło jedynie o pojawienie się kilku pomp próżniowych, wciąż można było je przyporządkować do jednej z dwóch klas: praw naturalnych lub reprezentacji politycznych. Kiedy jednak przeżywamy inwazję zamrożonych embrionów, systemów eksperckich, maszyn cyfrowych, robotów, modyfikowanej kukurydzy, banków danych, leków psychotropowych, wielorybów z nadajnikami, syntezatorów genów, telemetrii itd., kiedy nasze gazety szpalta po szpalcie prezentują te potwory, których nie sposób bezproblemowo umieścić ani po stronie przedmiotów, ani po stronie podmiotów (a nawet gdzieś pomiędzy), trzeba jakoś temu zaradzić", zob. B. Latour, Nigdy nie byliśmy nowocześni, przeł. M. Gdula, Oficyna Naukowa, Warszawa 2011, s. 74. 
dzie efektem powziętych przez nas zamiarów. ${ }^{2}$ Stanowiąc kolejny głos w serii wypowiedzi podważających ideę nowoczesności jako realnego, osiągniętego czy już przebytego stanu cywilizacji, ANT wprowadziła do refleksji humanistycznej namysł nad aktorami, definiowanymi jako wszelkie byty zdolne do działania. Są nimi nie tylko ludzie, ale i czynniki pozaludzkie: rzeczy, narzędzia, infrastruktury technologiczne, inne gatunki, a nawet ekosystemy. Podkreśla się tutaj, że aktorzy pozaludzcy częstokroć wytyczają ścieżki, którymi siłą rzeczy poruszają się ludzie realizując swoje zamiary. Mówiąc słowami samej ANT, teoria ta przypomniała o istnieniu aktorów, a właściwie sieci aktorów, rozpoznawalnych dzięki specyficznym cechom. Ze względu na dowartościowanie problemu sprawczości aktorów pozaludzkich, ANT określa się przy tym jako ujęcie posthumanistyczne.

ANT proponuje metodologię badań, których przedmiotem nie są stabilne, esencjonalne, dane z góry byty, ale procesy historyczne i relacyj$n \mathrm{e}^{3}$. Tego rodzaju procesem jest właśnie opieka nad zabytkami. Dlatego niniejszy tekst proponuje wykorzystanie ANT do lepszego zrozumienia roli konserwatorów, historyków sztuki, ale i techników, edukatorów, ogrodników, strażników, czy w końcu informatyków w procesie opieki nad kolekcjami zabytkowymi. Wszyscy oni są bowiem aktorami tworzącymi sieć powiazań, do której według ANT należą również w omawianym tu szczególnym przypadku obiekty architektury zabytkowej, kolekcje obrazów, rzeźb, mebli i tym podobnych. Pewne pozwalające się zaobserwować podczas codziennej praktyki konserwatorskiej epizody i trendy umożliwiają zidentyfikowanie aktorów pozaludzkich, kluczowych dla pracy konserwatora. Metodologia ANT rekomenduje możliwie bezstronne "podążanie za aktorami”, bez dookreślania z góry, z jakimi ontologicznymi kategoriami bytów mamy do czynienia. W tym właśnie duchu zamierzam prześledzić w prezentowanym tu studium przypadku proces prewencji konserwatorskiej w Muzeum Pałacu Króla Jana III w Wilanowie.

2 Obszerny przegląd rozwoju i aktualnego stanu badań STS czytelnik znajdzie w: Studia nad nauka i technologia. Wybór tekstów, red. E. Bińczyk i A. Derra, Wydawnictwo Naukowe UMK, Toruń 2014.

3 Jak bowiem czytamy: „Ogólnie biorąc, Teoria Aktora-Sieci zastępuje ontologię opartą na esencjalizmie (gdzie tożsamość bytów bazuje na konstytutywnych niezmiennych cechach wewnętrznych) ontologią relacyjną (tutaj owa tożsamość uzyskiwana jest poprzez relacje z innymi bytami)", zob. W. Wachowski, Wypić albo przeptynać. Recenzja książki Wszystko otwarte na nowo. Teoria Aktora-Sieci i filozofia kultury. "Avant. The Journal of the Philosophical-Interdisciplinary Vanguard”, Vol. II, Number T/2011, Ośrodek Badań Filozoficznych, 2011, www.avant.edu.pl/wp-content/uploads/Wypic_albo_przeplynac.pdf, s. 162 [dostęp 30.05.2017]. 


\section{Specyfika opieki nad zabytkami w Muzeum Pałacu Króla Jana III w Wilanowie}

O charakterze pracy, jaka jest obecnie wykonywana w Muzeum Pałacu Króla Jana III w Wilanowie w ramach opieki nad kolekcją dzieł sztuki najlepiej zaświadczy symptomatyczna zmiana nazwy Działu Konserwacji na Dział Prewencji i Konserwacji, dokonana w związku z reformą struktury Muzeum z końcem roku 2012. Pojęcie „konserwacja prewencyjna" pojawiło się po raz pierwszy w 1978 roku. W 1993 roku w Wytycznych Zawodowych ECCO (European Confederation of Conservators-Restorers' Organisations) omawianą aktywność przypisano zatrudnionym $\mathrm{w}$ muzeach konserwatorom ${ }^{4}$. Polega ona na pośrednim działaniu w celu opóźnienia procesów deterioracji i uniknięcia szkód poprzez stworzenie optymalnych warunków dla zachowania obiektu kulturowego, „zgodnie z jego społeczną użytecznością. W przypadku Muzeum Pałacu w Wilanowie oznacza to utrzymanie $\mathrm{w}$ nie pogorszonym stanie 10170 muzealiów tworzących kolekcję ${ }^{5}$. Specyfiką Muzeum Pałacu w Wilanowie (który jest rezydencją historyczną) jest fakt, że sam pałac jest $\mathrm{z}$ jednej strony cennym, wymagającym opieki zabytkiem, a z drugiej stanowi schronienie dla kolekcji, jest więc rodzajem skorupy lub gigantycznej gabloty mieszczącej ekspozycję historycznych wnętrz $\mathrm{i}$ ich wyposażenia. Wszystko to razem musi pozostawać w gotowości do codziennego udostępnienia zbiorów ewentualnej publiczności.

\section{Katalog ryzyk konserwatorskich i ich opiekunowie}

Przyjętym w świecie kluczem do pracy na polu prewencji konserwatorskiej jest katalog ryzyk konserwatorskich (katalog CCI) ułożony w latach 90. XX w. przez Stefana Michalskiego z Canadian Conservation Institute. Już na pierwszy rzut oka widać, że jest to zestawienie czynników zagrażających fizycznej kondycji wrażliwych materiałów, z których wykonane są zabytkowe obiekty. Katalog jest z pozoru krótki, ale poszczególne pozycje związane są z rozbudowanymi, wewnętrznymi strukturami przyczynowo-skutkowymi. Katalog ten całkowicie wyczerpuje listę znanych nam obecnie zagrożeń dla zabytkowych obiektów. Oto zesta-

4 Zob. A. Pawlak, Nowa rola konserwatora dzieł sztuki w zmieniajacym się muzeum (na przykładzie strategii ochrony zbiorów wypracowywanej w Muzeum Pałacu w Wilanowie, w: Archeologica Hereditas. Konserwacja zapobiegawcza środowiska, red. Z. Kobyliński, J. Wysocki, Warszawa-Zielona Góra 2012, s. 185-196.

5 Zgodnie z odczytem z bazy danych MONA, zwierającej Inwentarz Muzealny, oraz z bazy danych dekoracji fasad prowadzonej w systemie GIS, z dnia 25.10.2017. 
wienie rodzajów ryzyka, z poglądowym, choć ciągle tylko częściowym rozwinięciem pozycji czwartej:

1) siły fizyczne,

2) przestępczość,

3) ogień,

4) woda: a. powódź; b. przeciek z dachu; c. wyciek z instalacji; d. kondensacja pary itd.,

5) zagrożenia natury biologicznej,

6) zanieczyszczenia,

7) światło/promieniowanie UV,

8) niewłaściwa temperatura $(\mathrm{T})$,

9) niewłaściwa wilgotność względna $(\mathrm{RH})^{6}$.

W Muzeum Pałacu w Wilanowie przyjmuje się, że tak jak obiekty kolekcji mają swoich opiekunów dbających o ich stan materialny i stan wiedzy o nich, tak samo poszczególne ryzyka konserwatorskie, to znaczy czynniki skutkujące pogorszeniem stanu obiektów tworzących kolekcję również powinny mieć swoich „opiekunów” lub „właścicieli”, których rolą jest „zarządzanie" poziomem określonego ryzyka. Zarządzanie jest tu rozumiane literalnie, zgodnie z metodologią zarządzania projektami Prince2 ${ }^{7}$. Metodologia ta określa systematyczne stosowanie procedur w celu identyfikowania szans i zagrożeń, dokonywania oceny prawdopodobieństwa, wpływu i bliskości oraz ogólnego poziomu ryzyka w danym zadaniu, a także planowania i wdrażania reakcji na ryzyko.

\section{Bazowe wytyczne metodologii ANT}

Z zarysowanej wyżej perspektywy dają się już zaobserwować trzy obszary włączone $\mathrm{w}$ proces prewencji konserwatorskiej: kolekcja, opiekunowie kolekcji i opiekunowie poszczególnych rodzajów ryzyka konserwatorskiego. Nie trzeba Teorii Aktora-Sieci, by stwierdzić, że to z całą pewnością nie wszystko, co decyduje o przebiegu procesu opieki nad kolekcją. Jednakże trzeba ANT, a zwłaszcza jej specyficznej metodologii, żeby w sposób bezstronny (i dlatego najbardziej z dostępnych rzetelny)

6 Za: R. Waller, Conservation risk assessment: a strategy for managing resources for preventive conservation, Vol. 39, Supl. 2: Preventive Conservation: Practice, Theory and Research, Taylor\&Francis, 1994, s. 12-16.

7 Prince2 (Projects In Controlled Environments) to metodyka zarządzania projektami (termin „projekt” występuje tu jako kalka z ang. „project”, czyli przedsięwzięcie) uformowana ostatecznie w 1996 r. w Wielkiej Brytanii jako ogólna metoda zarządzania projektami, niezależna od dziedziny zastosowania biznesowego. W Muzeum Pałacu w Wilanowie został wdrożony zadaniowy system zarządzania, co zostało poprzedzone szeregiem szkoleń, w wyniku których certyfikat Prince2 uzyskało około 60 pracowników ze wszystkich działów. 
opisać dyskutowany tu proces. Oto podstawowe wytyczne metodologii ANT:

1. Przedmiotem badań nie są stabilne, esencjonalne byty, ale procesy historyczne i relacyjne.

2. Obowiązuje agnostycyzm, w związku z czym należy:

a) unikać imputacji ontologicznych,

b) unikać redukcji a priori,

c) zawiesić automatyczne rozróżnianie kategorii ontologicznych,

d) podążać (bezstronnie) za aktorami,

3. Czynniki pozaludzkie:
a) stawiają opór pewnym ich użyciom w praktyce naukowej czy technicznej,
b) nie sposób wyizolować ich (jako samej przyrody czy czystych faktów, nieskażonych interwencjami człowieka), jeśli są źró- dłem oporu,
c) należy każdorazowo przeprowadzić studium przypadku i zre- konstruować historię wyłaniania się nowego aktora.

4. Każdy element sieci ma głos rozstrzygający, czyni różnicę i stawia opór.

5. Niezależność czynników pozaludzkich polega każdorazowo na konkretnym ustabilizowaniu się sieci powiązań.

\section{Mapowanie sieci najważniejszych akłorów}

Wchodząc w Muzeum w Wilanowie na pewien czas w rolę badacza mrówki', by podążać za aktorami, uczestniczyłem bezpośrednio w pracach pewnych zespołów zadaniowych, a także obserwowałem pracę innych zespołów, w niektórych przypadkach przeprowadzając wywiady. Rekonstruowałem $\mathrm{w}$ ten sposób sieć powiązań składających się na proces prewencji konserwatorskiej w Muzeum Pałacu Króla Jana III w Wilanowie. Mówiąc o sieci, mówimy także o pewnej przestrzeni. Jak zatem sądzę, przedstawienie przestrzenne, czyli mapa, będzie najlepszym sposobem prezentacji wyników mojego badania.

8 E. Bińczyk, Program badawczy Bruno Latoura i jego zalety w kontekście badań nad światem wspótczesnym, w: Teoretyczne podstawy socjologii wiedzy, t. 1, red. P. Bytniewski, M. Chałubiński, Wydawnictwo UMCS, Lublin 2006, https://repozytorium.umk.pl, s. 4-6 [dostęp 25.05.2017].

9 ANT w języku angielskim znaczy też „mrówka”, i jest to w środowisku badaczy pracujących z Teorią Aktora-Sieci ceniona metafora. Metafora ta uwypukla fakt, że badacze ANT dokonują szczegółowych, „mrówczych” analiz w poszczególnych studiach przypadków. 
Rezultaty pozwalają na uchwycenie sieci powiązań w omawianym procesie, a także wykazanie wzajemnego oddziaływania pomiędzy najważniejszymi aktorami. Identyfikuję i lokuję aktorów niezależnie od tego, do jakiej kategorii ontologicznej są oni tradycyjnie zaliczani (oznacza to, że na wspomnianej mapie umieszczam zarówno czynniki ludzkie, pozaludzkie, jak i hybrydy). Na zamieszczonym niżej diagramie można znaleźć tak różne (heterogeniczne) byty, jak: „konserwatorzy”, „,sieci przesyłowe”, , ,komunikacja”, „,budżet”, ,"kotłownia” (która reprezentuje tu infrastrukturę i kadrę techniczną), "dyrekcja”, ,"kontrola dostępu" (pod tą nazwą kryją się dwa działy muzeum) czy "bazy danych”.

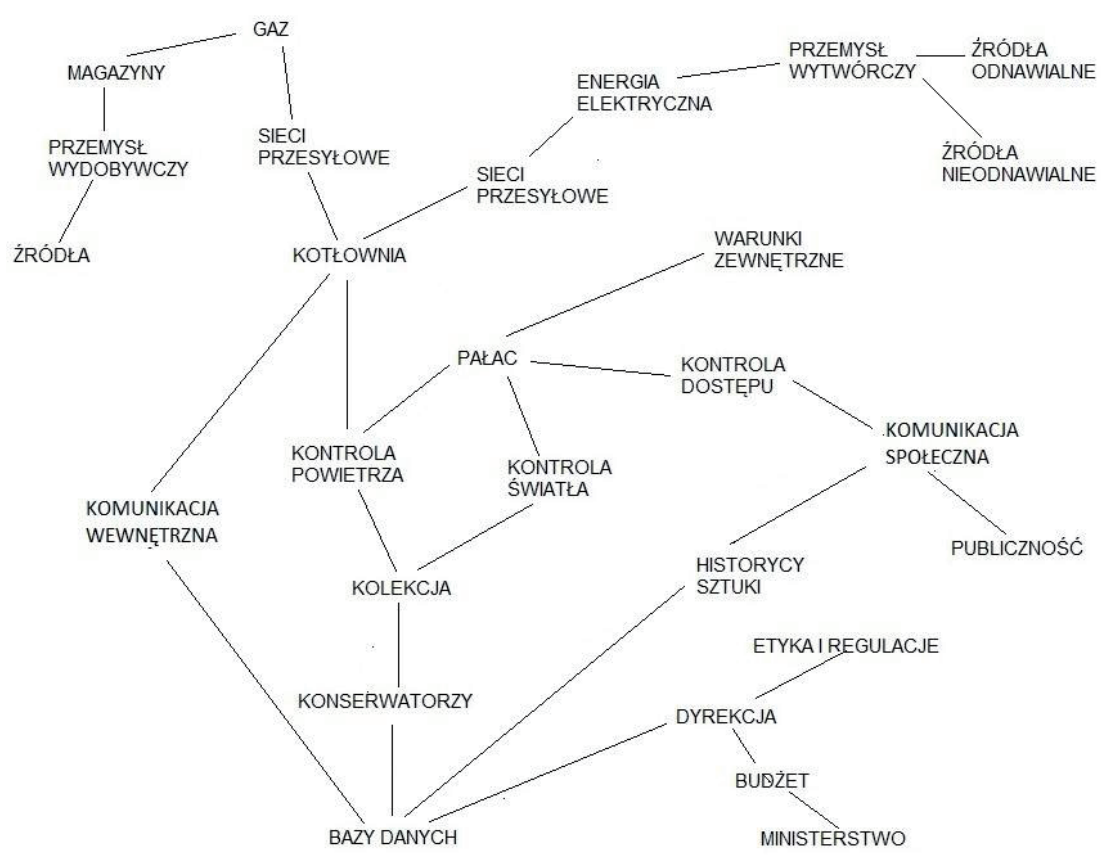

Rys. 1. Opieka nad kolekcją wilanowską. Sieć aktorów

\section{Czarne skrzynki}

W większości przypadków wskazane wyżej elementy, składające się na mapę sieci powiązań w procesie opieki nad kolekcją wilanowską takie jak "dyrekcja”, "bazy danych" czy "sieci przesyłowe”, to w sugestywny sposób ponazywane „czarne skrzynki”. Czarna skrzynka to metafora odnosząca się do zasady projektowania systemów złożonych z mniejszych elementów, których wewnętrzna budowa i działanie pozostaje, po dokładnym przetestowaniu, poza zainteresowaniami pro- 
jektanta ${ }^{10}$. Czarne skrzynki w ANT to węzły sieci, których wnętrza, jakkolwiek stanowiące niekoniecznie mniej skomplikowane sieci, nie są interesujące dla badania procesu opieki nad zabytkami wilanowskimi. Interesujące jest tylko oddziaływanie poszczególnych bytów na sieć. Termin „black-box” i jego specyficzne dla niniejszego badania rozumienie wywodzi się oryginalnie z cybernetyki i informatyki, ale z powodzeniem został on zaadaptowany przez ANT.

O tym, co przykładowo mogą zawierać sieci, możemy się przekonać, otwierając czarną skrzynkę o nazwie „kontrola powietrza”. Dowiadujemy się wtedy, że powietrze transferuje do wnętrz pałacu, a więc miejsca przechowywania kolekcji, sporą grupę czynników wynotowanych w katalogu ryzyk konserwatorskich. Będą to: niewłaściwa temperatura, niewłaściwa wilgotność względna, zanieczyszczenia oraz zagrożenia biologiczne. W Muzeum Pałacu Króla Jana III w Wilanowie istnieje w związku z tym rozbudowany aparat modyfikacji i kontroli powietrza. Należą do niego: nagrzewnice i nawilżacze, systemy filtrów na wlotach i wylotach sieci wentylacyjnych, rejestratory parametrów T i RH obsługiwane ręcznie lub przesyłające dane do bazy drogą radiowa, aplikacje informatyczne umożliwiające wizualizację danych, laboratorium mikrobiologiczne z mikroskopami, mobilne sondy do badania stopnia zapylenia powietrza, wykwalifikowani pracownicy kilku specjalności, a także zabytkowe drzwi i okna pałacu (jako ruchome i jakże często z zasady nieszczelne zagrody).

Wskazane wyżej elementy współdziałają mniej lub bardziej harmonijnie $w$ jednym celu: powietrze we wnętrzach pałacu ma być w jak największym stopniu pozbawione składników mogących powodować pogorszenie się stanu obiektów. Parametry tego powietrza muszą znajdować się $\mathrm{w}$ stanie określonej równowagi. Z punktu widzenia opieki nad zabytkami jest to jedyny ważny dla nas efekt, i nie interesuje nas sposób, w jaki zostaje uzyskany. Może on pozostać w czarnej skrzynce, ponieważ zajmuje nas teraz badanie procesu prewencji konserwatorskiej, a nie procesu kontroli parametrów powietrza.

Jeśli wziąć pod uwagę postulat ANT mówiący o tym, że nie należy z góry wyróżniać żadnych aktorów, oznacza on dla nas, iż żaden ze wspominanych wyżej czynników nie powinien mieć w sieci uprzywilejowanej pozycji. Jednakże jeśli ma się „,podążać za aktorami”, potrzebny jest przynajmniej początek drogi lub aktor, któremu przyjrzymy się jako pierwszemu, identyfikując jego bezpośrednie powiązania.

Omawiane powiązania między aktorami realizującymi proces prewencji konserwatorskiej w Muzeum Pałacu Króla Jana III w Wilanowie prowadzą oczywiście do kolejnych węzłów - aktorów sieci. Ich równo-

10 Zob. Z. Płoski, Słownik encyklopedyczny. Informatyka, Wydawnictwo Europa, Wrocław 2002. 
ważność bywa zaskakująca i nieoczywista. Dla przykładu: jeśli znajdujące się w kraju „magazyny” paliwa gazowego nie zostaną z różnych przyczyn, napełnione w wystarczającym stopniu lub sieci przesyłowe staną się z przeróżnych przyczyn niedrożne, nastąpi ograniczenie efektywności pracy „kotłowni” i pogorszą się warunki klimatyczne w pałacu. Oznacza to wzrost poziomu ryzyka niewłaściwych T i RH (poz. 8 i 9 z katalogu CCI), co może grozić tym, że stan kolekcji zacznie gwałtownie się pogarszać.

Wiąże się to z inna, dość kontrowersyjną kwestią: czy postulowana przez metodologię ANT symetryczna relacja między aktorami oraz ich równoważność jest w ogóle możliwa? Na przykład, skoro brak dopływu gazu niszczy kolekcję zabytków w Muzeum Pałacu Króla Jana III w Wilanowie, to czy pogorszenie stanu kolekcji wilanowskiej ma również wpływ na kondycję magazynów gazu? Jak sądzę, tak właśnie jest, albowiem muzeum jest cząstką komercyjnego rynku gazu, składającego się z mnóstwa odbiorców, i jego kłopot oznacza kłopot rynku, co automatycznie staje się problemem (jakkolwiek o innej wadze) dla magazynów gazu. Jest to przypadek rozgrywający się już w innej sieci, o wiele rozleglejszej.

\section{Konserwatorzy i kody}

Wybierzmy się jeszcze inną ścieżką łączącą kolekcję z pozostałymi aktorami, tym razem prowadzącą do węzła opisanego jako „konserwatorzy". Jest to tradycyjnie bardzo ważna grupa zawodowa w muzeum, odpowiedzialna za stan kolekcji. W procesie prewencji konserwatorzy pełnią specyficzną rolę obserwatorów, a ich aktywność polega paradoksalnie na robieniu wszystkiego, by nie trzeba było niczego konserwować ani restaurować, czyli przywracać do stanu sprzed niepożądanej zmiany. Konserwatorzy - jako grupa - stanowią węzeł sieci dlatego, że jako jedyni są kompetentni do tego, by odczytać sygnały od aktora zwanego "kolekcją". Znają oni bowiem objawy i przyczyny deterioracji poszczególnych materiałów, z których wykonane są obiekty składające się na kolekcję (wspomnianych przyczyn należy oczywiście szukać w katalogu rodzajów ryzyka konserwatorskiego). Do opisania tego, w jaki sposób „kolekcja” oddziałuje na sieć, służy pewien kod wykorzystywany w codziennej praktyce Muzeum. Jest to czterostopniowa skala stanu zachowania obiektów, mająca trzy równoległe wymiary: opisowy (stan dobry - brak objawów deterioracji, stan problematyczny - zły stan jednego elementu, stan niestabilny - niepożądany proces przebiega szybko, wreszcie, stan alarmujący - stan jednego elementu zagraża innym elementom obiektu), liczbowy $(1,2,3 \mathrm{~m} 4)$ oraz kolorystyczny (zielony, 
żółty, pomarańczowy i czerwony $)^{11}$. Po tym, gdy zostanie już wprowadzony przez konserwatorów do sporządzanych przez nich cyklicznie opinii konserwatorskich, kod staje się sygnałem przetwarzanym przez inne węzły sieci, które reagują na jego zmiany. Kolekcja spełnia zatem definicję Latoura mówiąca, że aktorem jest „każda istota, której udaje się modyfikować inną"12. W tym kontekście można by pokusić się o stwierdzenie, że kolekcja nie wymaga lepszych warunków przechowywania, tylko domaga się adekwatnych reakcji ze strony opiekunów poszczególnych ryzyk konserwatorskich.

\section{ANT i planowanie}

Przejdźmy do kolejnego pytania: czy ANT potrafi dostarczyć danych umożliwiających planowanie dalszej, skutecznej opieki nad zabytkami? Czy nasza rekonstrukcja może przydać się konserwatorom w przyszłości? Uważam, że jest to możliwe. Ścieżki na diagramie prowadzą bowiem do dwóch aktorów o wyjątkowym znaczeniu, jeśli chodzi o zachowanie stabilności opisanej przez nas sieci powiązań.

Ci szczególni aktorzy to „warunki zewnętrzne” i „publiczność”. Pod pierwszą nazwą kryją się zmiany klimatyczne, nazywane też globalnym ociepleniem. Katalog jego skutków przewiduje np. podniesienie się do końca stulecia poziomu wód oceanów i mórz o 0,8-1,2 m., pustynnienie, tropikalne ulewy, huraganowe wiatry, korozję spowodowaną kwaśnymi aerozolami niesionymi znad mórz w głąb lądu, wzrost stopnia zasolenia porowatych materiałów budowlanych, straty i przemiany w szacie roślinnej ogrodów historycznych, a także narastające ryzyko konfliktów zbrojnych wynikających z walk o dostęp do zasobów naturalnych ${ }^{13}$.

Z kolei etykietka „publiczność” skrywa w sobie problemy wynikające z antropopresji. Przede wszystkim chodzi o skutki gwałtownej urbanizacji dokonującej się w bezpośredniej bliskości wilanowskiego za-

11 Podana klasyfikacja stanu została zaczerpnięta z opinii konserwatorskich dotyczących 1308 dekoracji fasad pałacowych, sporządzanych dwa razy do roku (po okresie zimowym i po okresie letnim). Jak to wskazano w tekście, pałac jest sam w sobie cennym zabytkiem i podlega analogicznym procedurom co kolekcja we wnętrzach. Klasyfikacja stanu obiektów ruchomych tej samej, 4-stopniowej, skali przypisuje nieco inne znaczenia. Różnica pomiędzy dekoracjami fasad a muzealiami tworzącymi kolekcje we wnętrzach pałacu polega na tym, że obiekt ruchomy może być w każdej chwili usunięty z ekspozycji, co nie wchodzi w grę w przypadku dekoracji fasad.

12 B. Latour, Polityka natury. Nauki wkraczaja do demokracji, przeł. A. Czarnacka, Wydawnictwo Krytyki Politycznej, Warszawa 2009, s. 313.

13 C. Köhler, H. J. Schlennhuber, Climate Change and the World Cultural Heritage, w: Historic Gardens and Climate Change/Recommendations for Preservation, SPSG, Poczdam 2014, s. 42-45. 
łożenia pałacowo-parkowego, a także o efekty intensywnej rozbudowy siatki połączeń drogowych i lotniczych. Te dynamiczne procesy wymagają stałego monitorowania, zaplanowanych reakcji oraz organizowania sojuszy w każdej możliwej skali. Stanowi to o rosnącej odpowiedzialności służb muzealnych zajmujących się środowiskiem zewnętrznym, wliczając $\mathrm{w}$ to szeroko rozumiane otoczenie muzeum. Ich znaczenie w przyszłości powinno rosnąć.

\section{Nawigacja wśród (heterogenicznych) danych}

Drugim ważnym efektem zastosowania metodologii ANT do opisu procesu opieki nad zabytkami Muzeum Pałacu Króla Jana III w Wilanowie jest uwypuklenie znaczenia baz danych. Łatwość dostępu do nich, powszechne zastosowanie baz danych w obrębie muzeum, a także ich maksymalna przejrzystość i prostota mają niebagatelne znaczenie dla pracy konserwatorów. W Muzeum w Wilanowie od 2003 roku trwa proceder wiązania informacji z lokalizacją czyli miejscem, którego dana informacja dotyczy. Stwierdzono bowiem, że ze względu na konieczność zachowania ciągłości opieki nad zasobami odnalezienie się w przestrzeni bazodanowej powinno być równie naturalne i szybkie, jak odnajdywanie się $\mathrm{w}$ realnej przestrzeni muzeum. $\mathrm{W}$ realnym muzealnym świecie tylko nieliczni pracownicy muzeum, w specyficznych sytuacjach zapoznają się z numerami inwentarzowymi obiektów (obiektów tych jest przecież ponad 10 000), używając ich następnie do porozumiewania się. Nieco więcej osób zna prawidłowe nazwy obiektów, ale prawie wszyscy pracownicy wiedza, gdzie one się znajdują ${ }^{14}$. Nawigowanie kursorem po cyfrowych planach pałacu i "klikanie" w zaznaczone obiekty pozwala uzyskać natychmiastowy dostęp do owych tysięcy numerów inwentarzowych, dziesiątków tysięcy opinii konserwatorskich, fotografii, rysunków, wykresów, notatek, protokołów i opracowań naukowych. Mamy tu do czynienia z cyfrowym dostępem do strumienia heterogenicznych danych dotyczących każdego aspektu funkcjonowania muzeum ${ }^{15}$. Cyfrowe mapy poszczególnych kondygnacji pałacu wilanowskiego w rzeczywistości funkcjonują jako zdekonstruowane macierze ryzyk konser-

14 W. Bagiński, Using location-related knowledge to improve preventive maintenance of the Wilanow Palace Muzeum, w: Proceedings of the European Workshop on Cultural Heritage Preservation, red. M. Krüger, Fraunhofer IRB Verlag, Berlin 2011, s. 22-23.

15 November, Camacho-Hübner i Latour puentują to następująco: "Jak widzieliśmy wcześniej, w mapach uderza nas teraz nie to, że reprezentują świat „na zewnątrz," ale, że są pulpitami interfejsów obliczeniowych pozwalających określić nam kolejne oznaczenia drogowe, gdy poruszamy się po świecie", V. November, E. Camacho-Hübner, B. Latour, Wkraczajac na terytorium ryzyka. Przestrzeń w erze nawigacji cyfrowej, przeł. K. Abriszewski, „Kultura Popularna”, 2010, nr 3-4, (29-30), s. 119. 
watorskich, te zaś są nieustannie monitorowane i przeliczane - również dzięki analizie map. Postuluje się ponadto, by w sposób jak najbardziej konsekwentny rozwijać bazy przestrzenne, funkcjonujące na podstawie oprogramowania obsługującego Geographic Information System (GIS), zapewniającego użytkownikom intuicyjny i kontekstowy dostęp do informacji, oparty na takich samych zasadach działania, jak w przypadku popularnych i powszechnie dostępnych $\mathrm{w}$ Internecie map satelitarnych powierzchni Ziemi z funkcją wyszukiwania.

\section{Korzyści z przyjęcia perspekływy ANT}

Nie twierdzę oczywiście, że to dopiero dzięki ANT dowiadujemy się o zmianach klimatycznych i ich skutkach dla substancji zabytkowej, ani, że to dopiero ANT pozwala dostrzec wyjątkowe znaczenie baz danych. Za pośrednictwem Teorii Aktora-Sieci dowiadujemy się po prostu, że obydwa te obszary, ukazane na mapie jako czarne skrzynki opatrzone etykietami: „warunki zewnętrzne” i „bazy danych” także należą do sieci. Skrywa się w nich pewna wewnętrzna dynamika, którą struktura opiekuńcza, rozumiana jako społeczność heterogenicznych aktorów, musi stale brać pod uwagę, rewidując jednocześnie (świadomie bądź też nieświadomie) własną tożsamość. Przyjęcie perspektywy ANT prowadzi zatem do poszerzenia granic, $w$ których rozgrywa się proces opieki nad wilanowską kolekcja, sprawiając, że można skuteczniej identyfikować zarówno zagrożenia, jak i szanse, które $\mathrm{w}$ ramach procesu opieki wystąpią. Jest tak, ponieważ „ANT uparcie zajmuje się relacjami, a nie esencjami"16, w ramach zaś owych relacji nie można już dłużej ignorować ani sprawczości czynników pozaludzkich, ani postępującej hybrydyzacji poszczególnych aktorów.

\section{Rola schematu organizacyjnego muzeum}

W świetle mej wiedzy, stan regulacji prawnych, zasobów i rozwiązań technicznych stosowanych $\mathrm{w}$ toku opieki nad zabytkami w innych historycznych rezydencjach europejskich ${ }^{17}$ nie odbiega od tego, z czym

16 K. Abriszewski, Poznanie, zbiorowość, polityka. Analiza teorii aktora-sieci Bruno Latoura, Universitas, Kraków 2008, s. 10.

17 Muzeum w Wilanowie od 2006 r. jest członkiem ARRE (L'Associaton des Résidences Royales Européennes). Stowarzyszenie to zostało założone w 1996 r. z inicjatywy Pałacu w Wersalu w celu integrowania narodów Unii Europejskiej. Sieć zrzesza obecnie 26 organizacji zarządzających ponad 80 historycznymi siedzibami królewskimi w 15 krajach. 
mamy do czynienia w Muzeum Pałacu Króla Jana III w Wilanowie. Jednakże aktualny schemat organizacyjny muzeum ${ }^{18}$ zdecydowanie różni się od przypominających bardziej wojskowe ordre de bataille schematów typowych dla tamtych instytucji.

\begin{tabular}{|l|l|}
\hline \multicolumn{2}{|c|}{ Dyrektor } \\
\hline \multicolumn{2}{|c|}{$\begin{array}{l}\text { Zastępcy dyrektora, } \\
\text { pełnomocnicy } \\
\text { dyrektora }\end{array}$} \\
\hline
\end{tabular}

Rys. 2. Schemat organizacyjny Muzeum Pałacu Króla Jana III w Wilanowie ${ }^{19}$

18 Schemat ten stanowi załącznik graficzny do Zarządzenia $n r$ 9/2014 z dnia 18 kwietnia 2014 r. w sprawie nadania regulaminu organizacyjnego Muzeum Pałacu Króla Jana III w Wilanowie, podpisanego przez dyrektora Muzeum Pawła Jaskanisa. Zarządzenie to wprowadziło w życie "zrównoważone zarządzanie macierzowe, w którym zarządzanie zadaniowe, funkcjonując w stałej strukturze organizacyjnej, uzupełnia podział funkcji, kompetencji, obowiązków, uprawnień i odpowiedzialności pomiędzy komórkami organizacyjnymi, samodzielnymi stanowiskami pracy, pracownikami oraz innymi osobami fizycznymi i prawnymi pracującymi na rzecz Muzeum".

19 Schemat opublikowano za zgodą Dyrekcji Muzeum Pałacu Króla Jana III w Wilanowie. 
Schemat organizacyjny muzeum wilanowskiego zarazem reprezentuje, jak i sprawczo kształtuje opisaną wyżej rzeczywistość muzealną polegającą na nieskrępowanym nawiązywaniu relacji, stawianiu oporu, prowadzeniu negocjacji i zawiązywaniu sojuszy w bezustannym dążeniu do stabilizacji poszczególnych czarnych skrzynek, dzięki którym proces opieki nad kolekcją przebiega skutecznie. Impuls do zmiany lub opór mogą zaistnieć (z uzasadnionej przyczyny) w każdym miejscu, i biec lub oddziaływać w każdą stronę, także w wielu kierunkach jednocześnie. Schemat organizacyjny oczywiście nie zastępuje ani nie naśladuje naszkicowanej wcześniej, będącej rezultatem mego badania, mapy sieci aktorów (uczestników realnego procesu opieki nad kolekcją).

Zasadnicza, zamierzona i praktyczna wartość schematu organizacyjnego polega nie tyle na uporządkowaniu struktury zespołu ludzkiego, ile na określeniu i usankcjonowaniu struktury komunikacyjnej, umożliwiającej wspomniane wyżej nawiązywanie relacji. Jak widzimy, wewnętrzne jednostki organizacyjne, czyli działy muzeum zostały uszeregowane w porządku alfabetycznym, co świadczy o intencji zatarcia rozróżnienia na działy „ważne” i „mniej ważne” z punktu widzenia podstawowej misji muzeum ${ }^{20}$.

\section{Znaczenie procesu translacji}

Nie pozostaje to w sprzeczności z tym, że byty te same mogą równolegle inicjować, prowadzić lub być włączone $\mathrm{w}$ inne procesy. Wszyscy aktorzy wskazani w schemacie są zdolni dokonywać „,translacji”"21, oddziału-

${ }^{20}$ W Statucie Muzeum czytamy, że „do zakresu działania Muzeum należy: 1) upowszechnianie wiedzy o zabytkowej rezydencji Króla Jana III i zgromadzonych zbiorach, a także o dokonaniach Króla Jana II i Stanisława Kostki Potockiego oraz zdarzeniach, osobach, obyczajach, osiągnięciach, kulturze i nauce w epokach obu postaci; 2) zachowanie w stanie niepogorszonym i ochrona zasobów własnych kulturowego i naturalnego dziedzictwa o charakterze materialnym i niematerialnym; 3) kształtowanie wrażliwości poznawczej i estetycznej, w tym postaw patriotycznych i obywatelskich; 4) umożliwianie korzystania ze zgromadzonych zasobów dziedzictwa kulturowego". Zob. Statut Muzeum Pałacu Króla Jana III w Wilanowie, rozdz. 2.

${ }^{21}$ W Słowniku ANT dołączonym przez Latoura do książki Nadzieja Pandory termin ten jest wyjaśniony następująco: "Zamiast przeciwstawiać słowa światu, studia nad nauką, przez położenie nacisku na praktykę, pomnożyły liczbę terminów zapośredniczających, które skupiają się na transformacjach charakterystycznych dla nauk; podobnie jak „,inskrypcja” czy ",artykulacja”, translacja jest terminem przekraczającym (crisscrosses) nowoczesny układ. Dzięki swoim lingwistycznym i materialnym konotacjom, odnosi się do wszystkich przemieszczeń oddziałujących na aktorów, których mediacja jest niezbędna, aby zaszło jakiekolwiek działanie. W miejsce sztywnej opozycji kontekst - treść, łańcuchy translacji odnoszą się do pracy, przez którą aktorzy zmieniaja przemieszczają i przekładają (translate) swoje liczne i sprzeczne interesy", 
jąc $\mathrm{w}$ różnym zakresie na proces konsolidacji sieci. Translacjami w omawianym procesie opieki nad zabytkami wilanowskimi są na przykład przepisy i regulacje prawne, regulaminy wewnętrzne, inwentaryzacje, protokoły badań laboratoryjnych, plany, wykresy czy harmonogramy.

Translacje, będące specyficznymi reprezentacjami obecności aktorów, są w stosunku do nich "przemieszczone”. Dla przykładu obecność powłoczniczka gładkiego (Cylindrobasidium leave, Corticium leave) - grzyba toczącego zabytkowe drewno - nie jest przyjmowana do powszechnej wiadomości na podstawie oględzin przebarwień w obrębie jego siedlisk w elementach zabytkowej więźby dachowej, lecz na podstawie lektur serii protokołów z kontrolowanych hodowli laboratoryjnych, opinii konserwatorskich czy niezależnych ekspertyz mykologiczno-konstrukcyjnych, wprowadzonych do mniej lub bardziej publicznego obiegu informacji, albowiem to one mają moc oddziaływania i wpływania na innych uczestników procesu. Jak z tego wynika, obecność powłoczniczka gładkiego zostaje przełożona na protokół, ten na opinię, opinia zaś na ekspertyzę.

"Translacja" to "tłumaczenie”, chodzi tu bowiem o wyrażenie czyjejś obecności w danym procesie językiem innym niż „natywny”, czyli właściwy tylko dla opisów omawianego bytu. Jednak nie dotyczy ono znanego ze słowników zestawiania odpowiadających sobie słów w pary, gdyż koniecznym atrybutem translacji jest również wspomniane przemieszczenie, swoisty transfer obecności danego bytu do obszaru, w którym nie był on dostrzegany. Ostatecznym zaś rezultatem powinna być interakcja. Rozpoznanie translacji to istotny moment każdego procesu badawczego, ponieważ „,celem pracy translacji i mediacji jest ustanowienie takiej sieci, która będzie miała dużą liczbę stabilnych połączeń, co sprawi, że zyska ona status obiektywnego faktu"22.

W wyżej przytoczonym przypadku powłoczniczka gładkiego protokół mykologa będzie oddziaływać na konserwatora "piszącego" program konserwatorski, który doda tam odpowiednie zabiegi, po czym, przekształcając to w oferty i kosztorysy, posłuży się nimi jako reprezentacjami obecności grzyba w celu uzyskania od działu finansowo-księgowego niemałych funduszy na jego unieszkodliwienie.

zob. B. Latour, Nadzieja Pandory. Eseje o rzeczywistości w studiach nad nauka, przeł. K. Abriszewski, A. Derra, M. Smoczyński, M. Wróblewski, M. Zuber, Wydawnictwo Naukowe UMK, Toruń 2013, s. 178.

22 M. Wróblewski, Choroba zamknięta w czarnej skrzynce. O domykaniu i otwieraniu kontrowersji wokół ADHD, „Annales Universitatis Mariae Curie-Skłodowska”, vol. XXXV, z. 2, Wydawnictwo UMCS, Lublin, 2010, s. 134. 


\section{Podsumowanie}

W artykule ukazane zostały powody teoretyczne, tło metodologiczne oraz wyniki badania procesu opieki nad zabytkami wilanowskiej kolekcji. Będąc świadkiem kryzysu nowoczesności oraz otwarcia perspektywy posthumanistycznej, zaproponowałem zastosowanie metodologii ANT do rozpatrzenia owego procesu nie jako sekwencji ludzkich decyzji, a jako sekwencji relacji zachodzących w sieci heterogenicznych aktorów. Wskutek „podążania za aktorami” została rozwinięta i przeanalizowana mapa owej sieci. Zostały również szczegółowo rozpatrzone pojęcia "czarnej skrzynki" i "translacji”, są to bowiem kategorie ANT, które można zastosować do opisu codziennej praktyki muzealnej. Ponadto został omówiony schemat organizacyjny Muzeum w Wilanowie, stanowiący ilustrację świadomego podejścia instytucji do zarządzania toczącymi się $\mathrm{w}$ jego obrębie procesami poprzez relacje.

Reasumując, możemy stwierdzić, że w praktyce konserwatorskiej w żadnym momencie procesu opieki nad zabytkową kolekcją nie daje się wypreparować żadnego czynnika czy bytu esencjonalnie "czystego", trwałego, nienegocjowalnego, pozbawionego relacji z innymi bytami. Z tego powodu: „Potrzebujemy [...] języka ujmującego hybrydyczność otaczających nas zjawisk. Takiego języka dostarcza nam ANT"23. Jak już wspomniano, w opisie praktyki prewencji konserwatorskiej w muzeum wilanowskim zanika podział na podmiot i przedmiot, zawiązuje się natomiast sieć powiązań miedzy heterogenicznymi aktorami. Z kolei pojęcia „zabytku” czy "konserwacji”, rozumiane tak, jak w antropocentrycznym dyskursie konserwatorskim, tracą na wyrazistości oraz autonomii. Nie jest bowiem wcale tak, że to wyłącznie podmioty ludzkie okazują się sprawcze i działają.

\section{Streszczenie}

\section{Opieka nad zabytkami z perspektywy posthumanistycznej. Przypadek kolekcji wilanowskiej}

W artykule ukazane zostały powody teoretyczne, tło metodologiczne oraz niektóre wyniki badania procesu opieki nad zabytkami wilanowskiej kolekcji. Będąc świadkiem kryzysu nowoczesności oraz otwarcia perspektywy posthuma-

23 E. Bińczyk, op. cit., s. 9. 
nistycznej, proponuję zastosowanie metodologii ANT do rozpatrzenia owego procesu nie jako sekwencji ludzkich decyzji, a jako sekwencji relacji zachodzących w sieci heterogenicznych aktorów. Wskutek „podążania za aktorami” została rozwinięta i przeanalizowana mapa owej sieci. Zostały również szczegółowo rozpatrzone pojęcia "czarnych skrzynek" skrzynki”, i „translacji” jako kategorie ANT, które można zastosować w opisie codziennej praktyki muzealnej. Ponadto został omówiony schemat organizacyjny Muzeum Pałacu w Wilanowie jako ilustracja świadomego podejścia instytucji do zarządzania toczącymi się w jego obrębie procesami poprzez relacje. Tekst postuluje zastosowanie języka znoszącego dychotomiczną relację podmiot-przedmiot do opisu opieki nad zabytkami.

Słowa kluczowe: ANT, Teoria Aktora-Sieci, ujęcie posthumanistyczne, sprawczość czynników poza-ludzkich, opieka nad zabytkami, muzeum, prewencja konserwatorska

\section{Summary}

\section{A posthumanist approach to heritage conservation. The case of the Wilanow collection}

This text presents the reasons, the background and some results of the study on preventive maintenance of the historic collection in the Museum of the Palace King Jan III in Wilanow. Being a witness of the crisis of modernity and the opening of a posthuman approach, I propose to use the methodology inspired by Actor-Netwok Theory (ANT) to envisage the mentioned above process as constituted by heterogenous actors-network rather than a personal decision-making sequence. By following the actors, a chart of the museum actor-network has been developed and analyzed. „Black-boxing” and „translations" have been identified and explained in detail as these ANT categories are most recognizable within the museum's everyday practices. There is also presented an organisational diagram of the Musem in Wilanow as an exact reflection of the ANT approach to the museum's activities. In general, this study supports the necessity of using a new language to describe the reality which cancels modern subject-object dichotomy.

Keywords: Actor-Network Theory, posthumanist approach, non-human agency, museum, preventive conservation 